\title{
SINTESIS DAN KARAKTERISASI WOLLASTONIT BERBAHAN DASAR ALAMI DENGAN METODE HIDROTERMAL
}

\author{
Rianda, Zulhadjri, dan Syukri Arief \\ Jurusan Kimia, Fakultas Matematika dan Ilmu Pengetahuan Alam, Universitas Andalas, \\ Kampus Limau Manis, Padang, 25163 \\ Email: riandarizal1989@gmail.com
}

\begin{abstract}
Indonesia is one of huge paddy producing countries so that it also produces rice husk in a great number. Rice husks contain high silica. Which is good in silica compounds synthesis such as Wollastonit $\left(\mathrm{CaSiO}_{3}\right)$. Nowadays Wollastonit has attracted great intension doe to its ability to increase mechanical properties of a material. In this work, rice husk was taken from Sariak Laweh, Lima Puluh Kota district and $\mathrm{CaO}$ was taken from Halaban, in the same district. Analysis with XRF show that $\mathrm{SiO}_{2}$ and $\mathrm{CaO}$ content of both samples were high enough, $97 \%$ and $98 \%$ which indicated their good potential as silica and calcium source in to synthesize of Wollastonit. Characterization XRD and SEM were found that the Wollastonit obtained which rice husks gave good result.
\end{abstract}

Keywords: Wollastonit, Hydrothermal, Rice husks ash, limestone.

\section{PENDAHULUAN}

Indonesia merupakan negara agraris dengan jumlah produksi padi yang besar. Sebagai salah satu provinsi penghasil padi Sumatra Barat menghasilkan limbah berupa sekam padi yang cukup banyak. Sekam padi merupakan limbah yang dihasilkan selama proses padi menjadi beras sekitar $20 \%$ dari berat padi ${ }^{[1]}$. Sekam padi memiliki kandungan silika yang besar dan merupakan material yang bagus untuk mensintesis persenyawaan silika ${ }^{[2]}$ Salah satu persenyawaan silika adalah Wollastonit $\left(\mathrm{CaSiO}_{3}\right)$.

Wollastonit belakangan ini menjadi perhatian para peneliti. Hal ini dikarenakan wollastonit dapat meningkatkan ketahanan gesekan, ketahanan peakaian, ketahanan panas suaut material $^{[3]}$. Oleh karena itu, wollastonit banyak digunakan pada industri keramik, semen, cat, kertas, plastik, aplikasi elektronik, dan dalam bidang medis ${ }^{[4,5]}$.
Ratchadaporn, dkk telah berhasil melakukan sintesis wollastonit dengan metode hidrotermal menggunakan cangkang telur sebagai sumber $\mathrm{CaO}$ dan diatomite sebagai sumber silika. Mereka menyimpulkan metode hidrotermal mudah dilakukan dan dapat menggunakan bahan dasar yang murah dalam mensintesis wollastonit ${ }^{[5]}$. Kelebihan lain dari metode hidrotermal adalah dapat dilakukan pada suhu rendah dengan tekanan yang tinggi dan dapat menghasilkan wollastonite dengan kemurnian yang tinggi ${ }^{[6]}$. Pada penelitian ini dilakukan sintesis wollastonit dengan menggunakan metoda hidrotermal menggunakan bahan dasar sekam padi sebagai sumber silika dan batu kapur sebagai sumber $\mathrm{CaO}$. Sekam padi diambil dari tempat penggilingan padi di daerah Sariak Laweh, sedangkan batu kapur diambil dari tempat penambangan batu kapur di daerah Halaban, yang kedua daerah ini masuk ke dalam Kabupaten Lima Puluh Kota. 


\section{METODOLOGI PENELITIAN}

\section{Prosedur Penelitian}

Pada penelitian ini, silika didapatkan dari pembakaran sekam padi. Sekam padi yang digunakan diambil dari tempat penggilingan padi yang berada di daerah Sariak Laweh, Kabupaten Lima Puluh Kota. Sekam padi di cuci dengan aquadest lalu dikeringkan didalam oven selama 1 jam dengan suhu $190^{\circ} \mathrm{C}$. Proses pemanasan dilanjutkan pada suhu $300^{\circ} \mathrm{C}$ selama 30 menit lalu dengan suhu $600^{\circ} \mathrm{C}$ selama 2 jam. Batu kapur yang didapatkan dari tempat penambangan batu kapur di daerah Halaban Kabupaten Lima Puluh Kota dalam bentuk serbuk dikalsinasi pada suhu $1000^{\circ} \mathrm{C}$ selama 5 jam. Sampel abu sekam padi dan batu kapur yang telah dikalsinasi ditentukan komponen penyusunnya menggunakan alat XRF.

Abu sekam padi dan $\mathrm{CaO}$ dilarutkan dengan air dengan konsentrasi 0,5 M. Kedua larutan ini di masukan ke dalam autoklaf lalu dipanaskan di dalam oven pada suhu $150^{\circ} \mathrm{C}$ selama $24 \mathrm{jam}$. Endapan putih yang didapat lalu dikalsinasi pada suhu $1100{ }^{\circ} \mathrm{C}$ selama 24 jam. Selain menggunakan abu sekam padi, silika gel juga digunakan sebagai sumber silika dalam penelitian ini. Hasil yang di dapat setelah sintesis dari penelitian ini dikarakterisasi menggunakan alat XRD, SEM dan EDX.

\section{HASIL DAN DISKUSI}

Kandungan silika dari abu sekam padi dan $\mathrm{CaO}$ dari batu kapur yang telah dikalsinasi ditentukan dengan melakukan pengujian menggunakan alat XRF yang ditunjukan pada Tabel 1.

Hasil XRF menujukan kandungan silika dalam abu sekam padi yang telah di kalsinasi sebesar $97,15 \%$. Kandungan silika yang didapat dalam penelitian ini relatif lebih besar apabila dibandingkan dengan penelitian yang telah dilakukan Ezzat Rafiee dkk, dimana kandungan silika yang didapatkan adalah sekitar $90,47 \%{ }^{[2]}$. Vinh Pham yang juga melakukan sintesis silika dari sekam padi dan mendapatkan kandungan silika dalam abu sekam padi sebesar $94,5 \%{ }^{[7]}$. Batu kapur yang telah dikalsinasi memiliki kandungan $\mathrm{CaO}$ yang cukup besar yaitu $98,37 \%$. Hasil ini memiliki perbedaan yang tidak jauh dari yang dilakukan Hamisah ismail, $\mathrm{dkk}^{[8]}$. Mereka mendapatkan persentase $\mathrm{CaO}$ dari batu kapur yang telah dikalsinasi adalah sebesar $97,22 \%$.

Pengukuran XRD dilakukan untuk melihat terbentuk atau tidaknya senyawa wollastonit. Sampel yang diukur dengan menggunakan XRD adalah sampel yang disintesis menggunakan abu sekam padi dan silika gel sebagai sumber silika. hasil XRD dari perbandingan sumber silika tersebut ditunjukan pada Gambar 1.

Tabel 1. Hasil XRF Bahan Dasar

\begin{tabular}{ccc}
\hline & Kandungan & $\%$ \\
\hline Abu Sekam Padi & $\mathrm{Al}_{2} \mathrm{O}_{3}$ & 0,422 \\
& $\mathrm{SiO}_{2}$ & 97,15 \\
$\mathrm{P}_{2} \mathrm{O}_{5}$ & 0,946 \\
$\mathrm{~K}_{2} \mathrm{O}$ & 0,558 \\
$\mathrm{CaO}$ & 0,726 \\
$\mathrm{Mn}$ & 0,101 \\
& $\left(\mathrm{Ti}, \mathrm{Fe}_{2} \mathrm{O}_{3}, \mathrm{Cu}, \mathrm{Zn}, \mathrm{Rb}, \mathrm{Sr}, \mathrm{Ag}, \mathrm{Ba}\right)$ & 0,097 \\
Batu Kapur Setelah & $\mathrm{CaO}$ & 98,37 \\
Dikalsinasi & $\mathrm{MgO}$ & 1,01 \\
& $\mathrm{SiO}_{2}$ & 0,63 \\
& $\mathrm{Al}_{2} \mathrm{O}_{3}$ & 0,14 \\
$\mathrm{Fe}_{2} \mathrm{O}_{3}$ & 0,02 \\
\hline
\end{tabular}




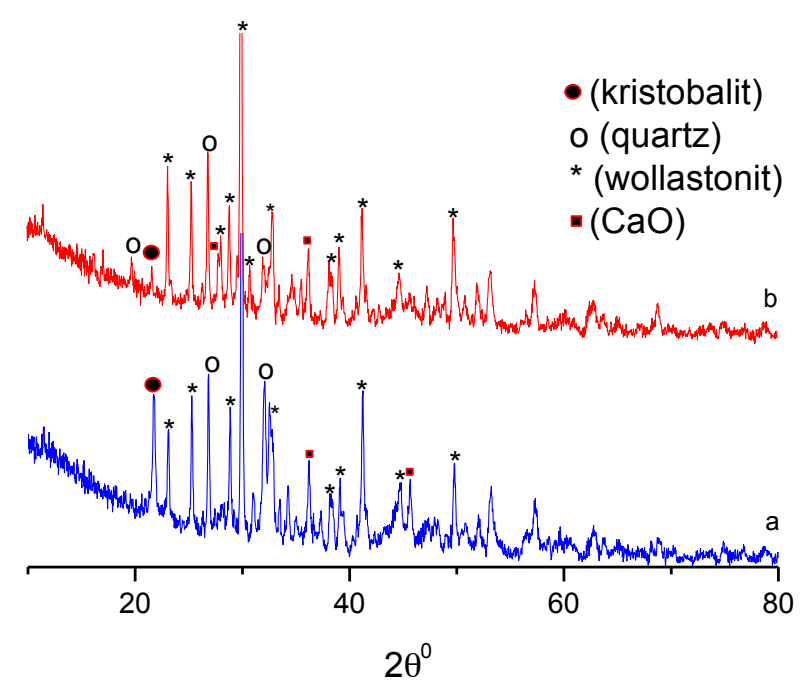

Gambar 1. Analisa XRD Sampel: [A] Abu Sekam Padi, [B] Silika Gel

Gambar 1a merupakan sampel yang disintesis menggunakan abu sekam padi dan Gambar 1b merupakan sampel yang disintesis menggunakan silika gel. Hasil XRD pada Gambar 1 menunjukan wollastonit terbentuk pada kedua sampel yang disintesis. Hal ini ditandai dengan munculnya puncak dengan intensitas tertinggi pada $2 \theta=29,9$ yang merupakan puncak utama dari wollastonit (ICSD: 01-076-0186) dan puncak-puncak dengan intensitas yang tinggi juga muncul pada $2 \theta=23,1 ; 25,3 ; 26,8 ; 28,8 ; 29,9$ yang semuanya merupakan puncak-puncak wollastonit (ICSD: 01-076-0186).

Selain puncak wollastonit, pada kedua sampel masih muncul puncak puncak bahan dasar seperti puncak $\mathrm{CaO}$, quartz, dan kristobalit. Sampel yang disintesis menggunakan abu sekam padi menunjukan puncak kristobalit yang muncul memiliki intensitas yang jauh lebih besar dibandingkan dengan yang disintesis menggunakan silika gel. Puncak kristobalit dengan intensitas yang tinggi dikarenakan masih banyaknya silika yang bersisa setelah proses hidrotermal berlangsung sehingga waktu dilakukan kalsinasi, silika yang tidak bereaksi akan membentuk struktur kristobalit.

Munculnya puncak kristobalit dengan intensitas yang tinggi pada sampel yang disintesis menggunakan abu sekam padi dipengaruhi oleh ukuran partikel abu sekam padi yang relatif lebih besar apabila dibandingkan dengan partikel silika gel. Karena memiliki ukuran partikel yang besar maka reaksi yang berlangsung antara silika dari sekam padi dan $\mathrm{CaO}$ tidak sempurna. Hal ini juga terlihat dari tingginya intensitas puncak $\mathrm{CaO}$ yang terbentuk pada hasil XRD (Gambar 1a). Sedangkan pada sampel yang di sintesis dengan menggunakan silika gel intensitas puncak $\mathrm{CaO}$ yang muncul tidak setinggi intensitas puncak yang muncul pada sampel lainnya. Hal ini sama dengan yang disimpulkan oleh Araz Yazdani dkk yang melakukan sintesis wollastonit dengan menggunakan silika $(30-40 \mu \mathrm{m})$ dan nano silika $(<100 \mathrm{~nm})$. Mereka menyimpulkan dengan menggunakan nano silika wollastonit yang terbentuk meningkat apabila dibandingkan dengan menggunakan dengan menggunakan silika ${ }^{[3]}$.

Hasil SEM dari sampel wollastonit yang disintesis menggunakan abu sekam padi dan silika gel yang ditunjukkan pada Gambar 2 . Gambar 2 menunjukkan, sampel yang disintesis menggunakan abu sekam padi dan silika gel sebagai sumber silika memberikan bentuk yang teraglomerasi. Sampel yang disintesis menggunakan silika gel sebagai sumber silika memberikan bentuk partikel yang seragam (Gambar 2a) apabila dibandingkan sampel yang disintesis dengan menggunakan abu sekam padi (Gambar 2b). Analisis EDX dilakukan terhadap sampel yang disintesis menggunakan abu sekam padi. Hasil EDX di tunjukan pada Tabel 2. Hasil EDX menunjukan pengotor-pengotor dari abu sekam padi seperti Mn, Al, Ti, Fe, dll. (Tabel 1) tidak ditemukan lagi. 


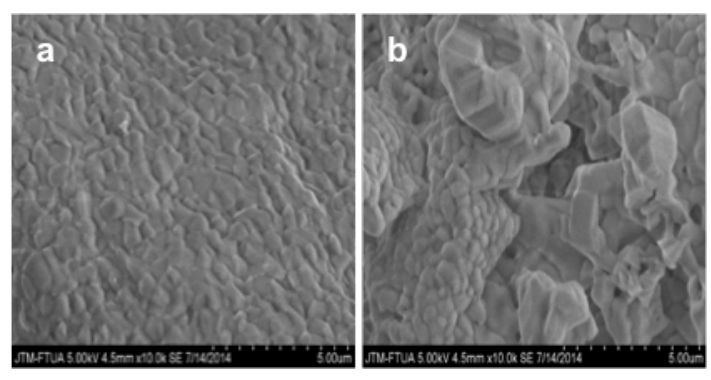

Gambar 2. Foto SEM dari Sampel Wollastonit yang Disintesis Mengguanakan Pelarut Air dengan Sumber Silika (a) Silika Gel, (b) Abu Sekam Padi.

Tabel 2. Hasil EDX Sampel yang Disintesis Menggunakan Abu Sekam Padi Sebagai Sumber Silika

\begin{tabular}{cc}
\hline Element & \% Berat \\
\hline $\mathbf{C}$ & 5,03 \\
$\mathbf{O}$ & 60,70 \\
$\mathbf{S i}$ & 18,39 \\
$\mathbf{C a}$ & 15,18 \\
\hline
\end{tabular}

\section{KESIMPULAN}

Dari penelitian ini dapat disimpulkan Wollastonit dapat disintesis secara mudah dan murah menggunakan metoda hidrotermal berbahan dasar abu sekam padi sebagai sumber silika dan batu kapur sebagai sumber $\mathrm{CaO}$. Metoda hidrotermal memberikan wollastonit dengan kemurnian yang baik. Abu sekam padi yang berasal dari daerah Sariak Laweh dan $\mathrm{CaO}$ dari daerah Halaban pada Kabupaten Lima Puluh Kota memiliki kandungan $\mathrm{SiO}_{2}$ dan $\mathrm{CaO}$ yang cukup besar sehingga dapat dijadikan bahan dasar dalam mensintesis wollastonit.

\section{UCAPAN TERIMA KASIH}

Penulis mengucapkan terima kasih kepada seluruh karyawan UPT Laboratorium Terpadu Kopertis Wilayah X dan
Laboratorium Kimia Material, Jurusan Kimia FMIPA Universitas Andalas.

\section{DAFTAR PUSTAKA}

1. Mansha, M., S. H. Javed, M. Kazmi, and N. Feroze. Study of rice husk ash as potential source of acid resistance calcium silicate. Adv. Chem. Eng.and Sci. 1 (2011) 147-153.

2. Rafiee, E., S. Shahebrahimi, M. Feyzi, and M. Shaterzadeh. Optimization of synthesis and characterization of nanosilica produced from rice husk (a common waste material. International Nano Lett. 2 (2012) 29.

3. Vichaphund, S., M. Kitiwan, D. Atong, P. Thavorniti. Microwave synthesis of wollastonite powder from eggshells. $J$. Eur. Cer. Soc. 31 (2011) 2435-2440.

4. Yazdani, A., H. R. Rezaie, and H. Ghassai. Investigation of hydrothermal synthesis of wollastonite using silica and nano silica at different pressures. J. Cer. Process. Res. 11 (2010) 348-353.

5. Puntharod, R., C. Sankram, N. Chantaramee, P. Pookmanee. Synthesis and characterization of wollastonite from egg shell and diatomite by the hydrothermal method. J. Cer. Process. Res. 14 (2013) 198-201.

6. Lin, K., J. Chang, J. Lu. Synthesis of wollastonite nanowires via hydrothermal microemulsion method. Mater. Lett. 60 (2006) 3007-3010.

7. Pham, Vinh. Utilization of rice husk ash in geo technology, aplicability and effect of the burning condition, Thesis, Faculty of Civil Engineering and GeoScience Technische Universiteit Delft, Netherlands, 2012.

8. Ismail, H., R. Shamsudin, M. A. A. Hamid, and A. Jalar. Synthesis and characterization of nano-wollastonit from rice husk ash and limestone. Mater. Sci. For. 756 (2013) 43-47. 